УДК 581. 19.577.355.3

DOI 10.18524/2077-1746.2015.2(37).55003

У. Я. Стамбульська, здобувач

ДВНЗ «Прикарпатський національний університет імені Василя Стефаника», кафедра біохімії і біотехнології, вул. Шевченка, 57, Івано-Франківськ, 76018, Україна, тел.: +380342596171, e-mail: ustambulska@yandex.ru

\title{
ВПЛИВ БІХРОМАТУ КАЛІЮ У СЕРЕДОВИЩІ ВИРОЩУВАННЯ НА БІОХІМІЧНІ ПОКАЗНИКИ РОСЛИН ГОРОХУ
}

\begin{abstract}
Вивчено вплив біхромату калію на деякі біохімічні показники у верхівкових листках рослин гороху сорту Альфа. Вирощування гороху за наявності солі хрому веде до інтенсифікації вільнорадикальних процесів, про що свідчить збільшення вмісту ТБК-активних продуктів. Однак, зростання активності гваяколпероксидази вказує на функціонування компенсаторних механізмів.
\end{abstract}

Ключові слова: горох, хром, антиоксидантні ферменти.

Агресивними забруднювачами, які згубно впливають на біосферу, є іони важких металів (ВМ), серед них і шестивалентний хром [5]. У низьких концентраціях ВМ, зокрема і хром, є життєво важливими компонентами рослинної клітини і необхідні для проходження процесів метаболізму (біосинтезу білків, нуклеїнових кислот, факторів росту, синтезу хлорофілу, підтримки структурної і функціональної цілісності мембран та ін.), проте у високих - спричинюють багато фізіологічних та біохімічних порушень [2]. Одним з механізмів токсичності хрому є посилення генерації активних форм кисню (АФК), які викликають окисні пошкодження білків, ліпідів та нуклеїнових кислот [10-12, 17, 28]. Як наслідок, це призводить до порушення обміну речовин та пригнічення росту рослин, фотосинтезу, зниження вмісту хлорофілу, активності деяких ферментів, деградацію хлоропластів і мітохондрій $[2,12,16,18,26]$. У відповідь на дію оксидативного стресу, індукованого ВМ, рослини задіюють ферментні або неферментні механізми антиоксидантного захисту, для підтримки про/антиоксидантної рівноваги клітин [10, 16, 21, 27]. За високої інтенсивності оксидативного стресу, спричиненого важкими металами, потужності антиоксидантної системи захисту недостатньо для уникнення окисних пошкоджень. Наскільки порушується функціонування антиоксидантної системи та як змінюються показники оксидативного стресу у рослин гороху, за умов дії важких металів, зокрема хрому, відомо недостатньо $[1,15,19]$. У зв'язку з цим метою роботи було дослідити перебіг вільнорадикальних процесів у рослин гороху посівного за дії різних концентрацій біхромату калію. 


\section{Матеріали та методи дослідження}

Об'єктом досліджень були рослини гороху посівного - Pisum sativum L. copту Альфа. Стерилізоване насіння пророщували протягом 5 діб у вологій камері. Рослини вирощували у 2-х кілограмових поліетиленових посудинах з використанням у якості субстрату річкового піску і поживної суміші Кнопа збідненої на азот (0,25 норми) [3]. Як джерело хрому для дослідних варіантів використовували водний розчин солі біхромату калію $\mathrm{K}_{2} \mathrm{Cr}_{2} \mathrm{O}_{7}$ в концентраціях 0,001 , 0,01 і 0,1 мілімоль/кг субстрату. В контрольний варіант розчин солі не вносили. Рослини вирощували при температурі $25 \pm 2{ }^{\circ} \mathrm{C}$ за умов 16-годинного світлового дня та освітленості 6300 Лк. Забір рослинного матеріалу здійснювали на 5-ту, 10-ту та 15 доби росту.

Верхівкове листя рослин гомогенізували у співвідношенні 1:10 маса/об'єм в середовищі, яке містило: 50 мМ калій-фосфатний буфер (pH 7,0), 0,5 мМ етилендиамінтетраацетат та 1 мМ фенілметилсульфонілфторид [23]. Отримані гомогенати центрифугували $\left(13000 \mathrm{~g}, 15 \mathrm{xв}, 4{ }^{\circ} \mathrm{C}\right)$ на центрифузі Eppendorf 5415R (Німеччина) [23] і у супернатантах визначали вміст карбонільних груп білків (КБ) [14], ТБК-активних продуктів (ТБКАП) [22], активність ферментів [6, 20] та концентрацію білка [9]. Каталазну активність визначали на спектрофотометрі СФ-46 (Ломо, СРСР), реєструючи зміну оптичного поглинання пероксиду водню при довжині хвилі 240 нм [6]. Для розрахунків використовували коефіцієнт молярної екстинції $\mathrm{H}_{2} \mathrm{O}_{2} 39,4 \mathrm{M}^{-1} \mathrm{~cm}^{-1}$ [6]. Активність гваяколпероксидази (ГПО) визначали на спектрофотометрі Spekol 211 (Carl Zeiss, Німеччина) при довжині хвилі 470 нм у пробі об'ємом 1,5 мл, реєструючи зміну оптичного поглинання внаслідок окислення гваяколу до тетрагваяколу [20]. Для розрахунків використовували коефіцієнт молярної екстинкції гваяколу $26600 \mathrm{M}^{-1} \mathrm{~cm}^{-1}$ [7]. Концентрацію білка визначали за методом Бредфорд [9]. Для визначення вмісту КБ і ТБКАП супернатанти змішували з 40\% ТХО у співвідношенні (маса/ об'єм) 1:1 та центрифугували 5 хв при 7000 об/хв. Осаджені білки використовували для визначення вмісту КБ, а супернатанти для визначення ТБКАП. Вміст КБ визначали за реакцією з 2,4-динітрофенілгідразином [14], використовуючи для розрахунків коефіцієнт молярної екстинції динітрофенілгідразонів $22000 \mathrm{M}^{-1} \mathrm{~cm}^{-1}$ [14]. Вміст ТБКАП визначали за методом Heath та Packer [22] i розраховували із використанням коефіцієнту молярної екстинкції ТБК2-МДА адукту $155000 \mathrm{M}^{-1} \mathrm{~cm}^{-1}$ [22]. Дані представлені як середнє \pm похибка середнього $(\mathrm{M} \pm \mathrm{m})$. Статистичне опрацювання здійснювали, використовуючи критерій Даннета.

\section{Результати та їх обговорення}

Накопичення хрому в рослинах впливає на метаболічні процеси, зокрема призводить до порушення обміну речовин та пригнічення росту, фотосинтезу, 
зниження вмісту хлорофілу, активності деяких ферментів, деградацію хлоропластів і мітохондрій $[8,26]$.

Рівень продуктів вільнорадикального окислення ліпідів та білків є маркером пошкоджень, спричинених стресовими факторами $[11,24,28]$. Показано, що вміст карбонільних груп білків у верхівковому листі гороху на 5-ту і 10-ту доби росту не змінювався відносно контролю у всіх дослідних варіантах (таблиця). Однак, у 15-ти добових рослин спостерігали зниження їхнього рівня порівняно до контролю за наявності різних концентрацій солі хрому в субстраті приблизно на 37 \%. Відсутність змін рівня карбонільних груп білків на початкових етапах онтогенезу може бути зумовлене ефективною дією антиоксидантної системи в стресових умовах, а зниження їхнього вмісту на 15 добу росту гороху - посиленням процесів деградації.

Таблиця

Вміст ТБК-активних продуктів та карбонільних груп білків у листках гороху за дії біхромату калію в різних концентраціях

\begin{tabular}{|c|c|c|}
\hline $\begin{array}{l}\text { Варіант } \\
\text { досліду }\end{array}$ & $\begin{array}{c}\text { Концентрація ТБКАП, } \\
\text { нмоль/г сирої маси } \\
\end{array}$ & $\begin{array}{c}\text { Вміст КБ, } \\
\text { нмоль/мг білка }\end{array}$ \\
\hline \multicolumn{3}{|c|}{ 5-ти добові рослини } \\
\hline Контроль & $59,0 \pm 7,8$ & $2,28 \pm 0,28$ \\
\hline 0,001 мМ К $\mathbf{C r}_{2} \mathrm{O}_{7}$ & $58,4 \pm 6,8$ & $2,64 \pm 0,30$ \\
\hline 0,01 мM K $_{2} \mathrm{Cr}_{2} \mathrm{O}_{7}$ & $72,0 \pm 6,0$ & $1,98 \pm 0,07$ \\
\hline 0,1 мМ К $_{2} \mathrm{Cr}_{2} \mathrm{O}_{7}$ & $79,6 \pm 2,5^{*}$ & $2,34 \pm 0,13$ \\
\hline \multicolumn{3}{|c|}{ 10-ти добові рослини } \\
\hline Контроль & $51,0 \pm 2,6$ & $1,90 \pm 0,15$ \\
\hline 0,001 мМ К ${ }_{2} \mathrm{Cr}_{2} \mathrm{O}_{7}$ & $40,7 \pm 3,9$ *\# & $1,85 \pm 0,11^{\#}$ \\
\hline 0,01 мM K $_{2} \mathrm{Cr}_{2} \mathrm{O}_{7}$ & $63,2 \pm 1,7^{*}$ & $2,04 \pm 0,21$ \\
\hline $0,1 \mathrm{мM} \mathrm{K}_{2} \mathrm{Cr}_{2} \mathrm{O}_{7}$ & $66,6 \pm 3,2^{* \#}$ & $1,86 \pm 0,30$ \\
\hline \multicolumn{3}{|c|}{ 15-ти добові рослини } \\
\hline Контроль & $42,1 \pm 3,9^{\# *}$ & $2,15 \pm 0,20$ \\
\hline 0,001 мМ К $\mathrm{Cr}_{2} \mathrm{O}_{7}$ & $46,3 \pm 3,6$ & $1,55 \pm 0,19^{* \#}$ \\
\hline $0,01 \mathrm{мM} \mathrm{K}_{2} \mathrm{Cr}_{2} \mathrm{O}_{7}$ & $45,2 \pm 5,2^{\text {th }}$ & $1,56 \pm 0,08 *$ \\
\hline $0,1 \mathrm{мM} \mathrm{K}_{2} \mathrm{Cr}_{2} \mathrm{O}_{7}$ & $\mathbf{5 0 , 5} \pm \mathbf{7 , 4 ^ { \# \star }}$ & $1,57 \pm 0,19 * \#$ \\
\hline
\end{tabular}

Примітка. *Вірогідно відмінне від відповідного контрольного значення (без біхромату калію), "від відповідних значень на 5-ту добу та "від відповідних значень на 10 -ту добу з $P<0,05$, $(n=4)$. 
У відповідь на дію різних несприятливих чинників, зокрема іонів хрому, у клітинах суттєво зростає вміст ТБК-активних сполук, які є одними з кінцевих продуктів перекисного окислення ліпідів (ПОЛ) і слугують показником інтенсивності окислювальних процесів, зумовлених АФК $[4,8,11,17]$. У нашому експерименті на 5 добу росту вміст ТБКАП у рослин, вирощених в присутності 0,1 мМ біхромату калію був у 1,3 рази вищий, порівняно з контролем. Спостерігалася тенденція до зростання вмісту ТБКАП зі збільшенням концентрації солі в середовищі. У 10-ти добових рослин за наявності 0,01 та 0,1 мМ біхромату калію вміст ТБКАП був на 24 і 30 \% вищий, порівняно з таким у контролі. Отримані результати свідчать про те, що під впливом високих концентрацій іонів важких металів у середовищі послаблюються адаптаційні можливості рослин гороху і посилюється вільнорадикальне окислення. Зростання вмісту ТБКАП на 10 добу росту показано також іншими дослідниками на проростках кукурудзи [27]. У 15-ти добових рослин наявність солі хрому в середовищі росту не викликало достовірних змін даного показника. При цьому відбувалося зниження рівня ТБКАП зі збільшенням віку рослин. Відсутність різкої зміни інтенсивності процесів ПОЛ може свідчити про те, що стресова дія в цих умовах не вийшла за межі фізіологічних реакцій, а адаптивні механізми клітин контролюють розвиток окислювальних процесів [4].

У захисті рослин від стресу, викликаного важкими металами, важливе значення відіграють ферменти антиоксидантного захисту, такі як каталаза і гваяколпероксидаза [25]. Попередні дослідження показали підвищення активності каталази за надлишку іонів хрому в середовищі у рослин вігни [18] та базиліку [16]. Однак нами не виявлено відмінності у активності каталази за дії різних концентрацій біхромату калію у 5-ти і 10 -ти та 15 -ти добових рослин гороху (рис, А). У 15-ти добових проростків практично у всіх досліджуваних варіантах спостерігали підвищення активності каталази відносно попередніх 5 і 10 діб росту. Попередні дослідження показали, що у проростків рису хром зумовлював як індукцію, так і інгібування активності каталази $[25,26]$.
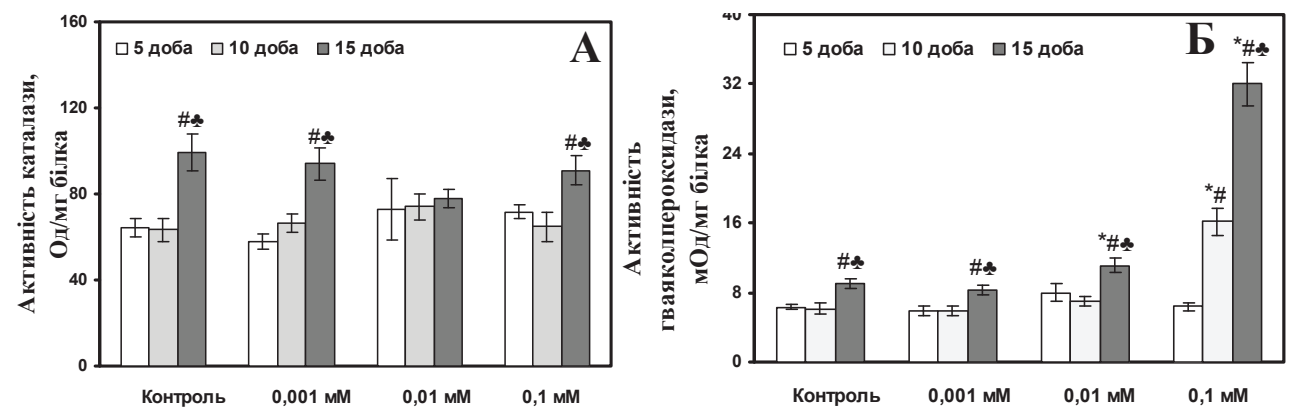

Рис. Активність каталази (А) та гваяколпероксидази (Б) у листках гороху при дї біхромату калію в різних концентраціях. *Вірогідно відмінне від відповідного контролю, ”від відповідних значень на 5-ту добу та *від відповідних значень на 10-ту добу з $P<0,05$, $(n=4)$. 
ГПО є одним з ферментів, задіяних у регуляції окисно-відновного балансу в рослинних тканинах за дії екзогенних індукторів оксидативного стресу та пошкоджуючих чинників [13]. Показано, що на 5 добу росту не відбувалось змін у активності даного ферменту за дії біхромату калію (рис, Б). Однак, у 10-ти добових рослин, вирощених в присутності 0,1 мМ біхромату калію, активність ГПО була у 2,6 рази вищою за таку в контролі. У 15 -ти добових рослин, вирощених у середовищі з концентрацією біхромату калію 0,01 та 0,1 мМ активність ГПО була у 1,2 і 3,5 рази відповідно вищою, порівняно $з$ такою у контролі. Отримані результати узгоджуються з результатами інших вчених при дослідженні впливу різних концентрацій хрому на проростки кукурудзи [27] та базиліку [16]. Підвищення активності ГПО у даному експерименті може свідчити про те, що цей фермент одним з перших реагує на дію біхромату калію. Ймовірно, у гороху за використаних нами умов ГПО відігравала ключову роль у знешкодженні АФК, здійснюючи при цьому компенсаторну функцію в умовах відсутності змін активності каталази. Окрім того, відсутність реакції антиоксидантних ферментів каталази і ГПО у 5-ти добових проростків гороху за дії солі хрому може бути зумовлена початковим накопиченням хрому коренями рослин. Менше накопичення хрому на початкових етапах росту у надземній частині порівняно з коренями показано і на проростках базиліку [16] та ячменю [10].

\section{Висновки}

Проведені дослідження показали, що надлишок солі хрому в середовищі веде до посилення вільнорадикальних процесів, а саме призводить до збільшення вмісту ТБКАП у листках гороху за наявності 0,01 та 0,1 мМ біхромату калію у субстраті.

Наявність біхромату калію в середовищі не впливала на активність каталази за використаних умов, однак призводила до зростання активності ГПО за дії 0,01 та 0,1 мМ біхромату калію, що вказує на функціонування компенсаторних механізмів.

\section{Список використаної літератури}

1. Біланич М. М. Сучасний стан дослідження впливу важких металів на рослинний світ / М. М. Біланич // Вісник Прикарпатського національного університету ім. Василя Стефаника: серія біологія. - 2008. Вип. 12. - С. 161-174.

2. Денчиля-Сакаль Г. М. Реакції рослин конюшини на забруднення грунту солями цинку / Г. М. ДенчиляСакаль, В. І. Ніколайчук, А. В. Колесник, М. М. Вакерич // Вісник Дніпропетровського університету. Біологія. Екологія. - 2012. - Вип. 20, Т. 2. - С. 18-24.

3. Прянишников Д. Н. Агрохимия. - М.: Сельсхозгиз, 3 изд., 1940. - 644 с.

4. Щербаченко О. I. Вплив іонів важких металів на ростові та фізіолого-біохімічні реакції піщаних і водних культур моху Drepanocladus aduncus (Hedw.) warnst / O. І. Щербаченко // Біологічні студії. - 2012. - Т. 6 , № 2. - C. 179-188.

5. Яковлєва С. О. Вплив $\mathrm{Cr}^{6+}$ у середовищі вирощування на ріст коренів та активність в них нітратредуктази у чорнобривців прямостоячих і календули лікарської / С. О. Яковлева // Вісн. Запорізьк. держ. у-ту. 1998. - № 1. - C. 1-3.

6. Aebi H. Catalase in vitro / H. Aeby // Methods Enzym. - 1984. - Vol. 105. - P. 121-126. 
7. Ali M. B. Effects of temperature on oxidative stress defense systems, lipid peroxidation and lipoxygenase activity in Phalaenopsis / M. B. Ali, E. J. Hahn, K. Y. Paek // Plant Physiol. Bioch. - 2005. - Vol. 43. - P. $213-223$.

8. Antioxidant response system and chlorophyll fluorescence in chromium (VI)-treated Zea mays L. seedlings / J. Zou., K. Yu., Z. Zhang [et al.] // Acta Biologica Cracoviensia Series Botanica. - 2009. - Vol. 51, N 1. - P. $23-33$.

9. Bradford M. M. A rapid and sensitive method for the quantitation of microgram quantities of protein utilizing the principle of protein-dye binding / M. M. Bradford // Analyt. Biochem. - 1976. - Vol. 72. - P. $289-292$.

10. Changes induced by two chromium-containing compounds in antioxidative response, soluble protein level and amylase activity in barley seedlings / Z. Olteanu, L. Oprica, E. Truta [et al.] // Analele Stiintifice ale Universitatii» Alexandru Ioan Cuza» din Iasi Sec. II a. Genetica si Biologie Moleculara - 2012. - Vol. 13, N. 3 - P. 41-47.

11. Chromium effects on free radical processes in goldfish tissues: comparison of $\mathrm{Cr}(\mathrm{III})$ and $\mathrm{Cr}(\mathrm{VI})$ exposures on oxidative stress markers, glutathione status and antioxidant enzymes / O. I. Kubrak, O. V. Lushchak, J. V. Lushchak [et al.] // Comparative Biochemistry and Physiology, Part C. - 2010. - Vol. 152. - P. 360-370.

12. Chromium-induced physio-chemical and ultrastructural changes in four cultivars of Brassica napus L. / R. A. Gill, L. Zang, B. Ali [et al.] // Chemosph. - 2015. - Vol. 120. - P. 154-164.

13. Cosio C. Specific functions of individual class III peroxidase genes / C. Cosio, C. Dunand // J. Exp. Bot. - 2009. - Vol. 60. - P. 391-408.

14. Determination of carbonyl groups in oxidatively modified of proteins by reduction with tritiated sodium borohydride / A.-G. Lenz, U. Costabel, S. Shaltiel, R. L. Levine // Analyt. Biochem. - 1989. - Vol. 177. - P. 419-425.

15. Dixit $V$. Chromium ions inactivate electron transport and enhance superoxide generation in vivo in pea (Pisum sativum L. cv. Azad) root mitochondria / V. Dixit, V. Pandey, R. Shyam // Plant, Cell \& Environment. - 2002. - Vol. 25, N 5. - P. 687-693.

16. Effect of chromium accumulation on photosynthetic pigments, oxidative stress defense system, nitrate reduction, proline level and eugenol content of Ocimum tenuiflorum L. / V. Rai, P. Vajpayee, S. N. Singh, S. Mehrotra // Plant Sci. - 2004. - Vol. 167, N 5. - P. 1159-1169.

17. Effect of chromium and nitrogen form on photosynthesis and anti-oxidative system in barley / S. Ali, M. A. Farooq, M. M. Jahangir [et al.] // Biol. Plantarum. - 2013. - Vol. 57, N 4. - P. 758-763.

18. Effect of chromium and tannery effluent toxicity on metabolism and growth in cowpea (Vigna sinensis L. Saviex Hassk) seedling / K. Nath, S. Shyam, D. Singh, Y. K. Shanna // Res. Environ. Life Sci. - 2008. - Vol. 1. P. 91-94.

19. Gangwar $S$. Indole acetic acid differently changes growth and nitrogen metabolism in Pisum sativum L. seedlings under chromium (VI) phytotoxicity: implication of oxidative stress / S. Gangwar, V. P. Singh // Scientia horticulturae. - 2011. - Vol. 129, N 2. - P. 321-328.

20. Ghamsari L. Kinetics properties of guaiacol peroxidase activity in Crocus sativus L. corm during rooting / L. Ghamsari, E. Keyhani, S. Golkhoo // Iran. Biomed. J. - 2007. - Vol. 11. - P. 137-146.

21. Glutathione peroxidase, superoxide dismutase, and catalase inactivation by peroxides and oxygen derived free radicals / E. Pigeolet, P. Corbisier, A. Houbion [et al.] // Mech. Ageing Dev. - 1990. - Vol. 51. - P. $283-297$.

22. Heath R. L. Photoperoxidation in isolated chloroplast. I. Kinetics and stoichiometry of fatty acid peroxidation / R. L. Heath, L. Packer // Archi. Biochem. Biophys. - 1968. - Vol. 125. - P. 180-198.

23. Inactivation of genes, encoding tocopherol biosynthetic pathway enzymes results in oxidative stress in outdoor grown Arabidopsis thaliana / N. M. Semchuk, O. V. Lushchak, J. Falk [et al.] // Plant Physiol. Bioch. - 2009. Vol. 47. - P. 384-390.

24. Møller I. M. Oxidative modifications to cellular components in plants / I. M. Møller, P. E. Jensen, A. Hansson // Annu. Rev. Plant Biol. - 2007. - Vol. 58. - P. 459-481.

25. Panda S. K. Antioxidant efficiency in rice (Oryza sativa L.) leaves under heavy metal toxicity / S. K. Panda, M. H. Khan // J. Plant Biol. - 2003. - Vol. 30, N 1. - P. 23-30.

26. Panda S. K. Chromium stress in plants / S. K. Panda, S. Choudhury // Braz. J. Plant Physiol. - 2005. - Vol. 17, N 1. - P. 95-102.

27. Responses of the maize plant to chromium stress with reference to antioxidation activity / S. Maiti, N. Ghosh, C. Mandal [et al.] // Braz. J. Plant Physiol. - 2012. - Vol. 24, N 3. - P. 203-212.

28. The effect of potassium dichromate on free radical processes in goldfish: possible protective role of glutathione / O.V. Lushchak, O.I. Kubrak, M.Z. Nykorak [et al.] // Aquat. Toxicol. - 2008. - Vol. 87. - P. 108-114.

Стаття надійшла до редакції 29.05.2015 


\title{
У. Я. Стамбульская
}

ГВУЗ «Прикарпатский национальный университет имени Васыля Стефаныка», кафедра биохимии и биотехнологии, ул. Шевченко, 57, Ивано-Франковск, 76018 , Украина

\section{ВЛИЯНИЕ БИХРОМАТА КАЛИЯ В СРЕДЕ ВЫРАЩИВАНИЯ НА БИОХИМИЧЕСКИЕ ПОКАЗАТЕЛИ РАСТЕНИЙ ГОРОХА}

\author{
Резюме \\ Изучено влияние бихромата калия на некоторые биохимические показатели \\ верхних листьев растений гороха сорта Альфа. Выращивание гороха при на- \\ личии соли хрома приводит к интенсификации свободнорадикальных процес- \\ сов, о чем свидетельствует увеличение содержания ТБК-активных продуктов \\ (ТБКАП). Однако повышение активности гваяколпероксидазы указывает на \\ функционирование компенсаторных механизмов. \\ Ключевые слова: горох, хром, антиоксидантные ферменты.

\section{U. Ya. Stambulska} \\ Department of Biochemistry and Biotechnology, Precarpathian National University \\ named after Vasyl Stefanyk, 57 Shevchenko Str., Ivano-Frankivsk 76018, Ukraine.
}

\section{EFFECT OF POTASSIUM DICHROMATE IN THE ENVIRONMENT ON BIOCHEMICAL PARAMETERS OF PEA PLANTS}

\begin{abstract}
The aim of this study was to investigate the intensity of free radical processes in pea plants exposed to different concentrations of potassium dichromate.

Pea plants (Pisum sativum L.) were grown on the sand which contain potassium dichromate $\mathrm{K}_{2} \mathrm{Cr}_{2} \mathrm{O}_{7}$ in concentrations of $0.001,0.01$ and $0.1 \mathrm{mM}$ per $\mathrm{kg}$ of substrate. Plants leaves were harvested on the 5th, 10th and 15th days of growth. The concentration of carbonyl protein groups and thiobarbituric acid reactive substance (TBARS), catalase and guaiacole peroxidase activity were measured in apical leaves. The level of protein carbonyls was not changed in the apical leaves of pea as compared with controls in all experimental groups. Pea plants growing in the presence of potassium dichromate resulted to intensification of free radical processes as evidenced by the increased thiobarbituric acid reactive substance. The activity of catalase did not change in leaves of plant exposed to potassium dichromate. Guaiacole peroxidase activity increased by 1.2 and 3.5 fold in plant grown in the presence of 0.01 and $0.1 \mathrm{mM}$ potassium dichromate, respectively as compared to control. It can be suggested that guaiacole peroxidase play an important role in plant protection from potassium dichromate toxicity.
\end{abstract}

Keywords: pea, chromium, antioxidant enzymes. 